\title{
AKTIVITAS ANTIOKSIDAN BEKATUL LEBIH TINGGI DARIPADA JUS TOMAT DAN PENURUNAN AKTIVITAS ANTIOKSIDAN SERUM SETELAH INTERVENSI MINUMAN KAYA ANTIOKSIDAN
}

\begin{abstract}
(Antioxidant Activity Rice Bran Higher than Tomato Juice and the Decreasing of Total Antioxidant Activity Serum After High Antioxidant Beverage Intervention)
\end{abstract}

Evy Damayanthi ${ }^{1 *}$, Lilik Kustiyah ${ }^{1}$, Mahani Khalid $^{1}$, dan Henry Farizal ${ }^{1}$

3 Departemen Gizi Masyarakat, Fakultas Ekologi Manusia, Institut Pertanian Bogor, Bogor 16680. Telp: 0251-8621258; Fax: 0251-8622276

* Alamat korespondensi: Departemen Gizi Masyarakat, Fakultas Ekologi Manusia, Institut Pertanian Bogor, Bogor 16680. Email: evyimam@yahoo.com

\begin{abstract}
Recently, many foods were identified contain high antioxidant substances such as tomatoes and rice bran. The objectives of this research were to observe their total antioxidant activity values and the effect of intervention of high-antioxidant beverages (tomato juice and rice bran beverage) to total antioxidant activity on breast cyst women patient's blood serum. Subject consumed each of the beverages for 14 days. Blood samples were taken before the intervention, at the end of tomato juice intervention period and at the end of rice bran beverage intervention period. Total antioxidant activity on serum was determined by DPPH method. The ascorbic acid equivalent antioxidant capacity (AEAC) of rice bran greater than tomato juice is $28.74 \mathrm{mg} / 100 \mathrm{~g}$ and $1.87 \mathrm{mg} / 100 \mathrm{~g}$ respectively. The total antioxidant activity on serum was decreasing after tomato juice intervention $(p>0.05)$ but the decreasing of it was significantly shown after rice bran intervention $(p<0.05)$.
\end{abstract}

Key words: total antioxidant activity, breast cyst, tomato juice, rice bran beverage.

\section{PENDAHULUAN}

Antioksidan dalam arti biologis adalah senyawa yang mampu menangkal atau meredam dampak negatif oksidan dalam tubuh (Winarsi, 2007). Antioksidan bekerja dengan cara mendonorkan satu elektronnya kepada senyawa yang bersifat oksidan sehingga aktivitas senyawa oksidan tersebut bisa dihambat. Keseimbangan oksidan dan antioksidan sangat penting karena berkaitan dengan berfungsinya sistem imunitas tubuh. Kondisi tersebut terutama untuk menjaga integritas dan berfungsinya membran lipid, protein sel dan asam nukleat serta mengontrol transduksi signal dan ekspresi gen dalam sel imun (Meydani et al., 1995).

Reaksi oksidasi terjadi setiap saat di dalam tubuh dan memicu terbentuknya radikal bebas yang sangat aktif yang dapat merusak struktur dan fungsi sel. Namun, reaktivitas radikal bebas tersebut dapat dihambat oleh sistem antioksidan yang melengkapi sistem kekebalan tubuh (Halliwell dan Guteridge, 1991).

Pangan nabati merupakan bahan pangan yang penting untuk memperoleh fitonutrient, salah satunya adalah tomat. Tomat merupakan sayuran yang kaya akan berbagai senyawa antioksidan seperti likopen, alfa-karoten, beta- karoten, lutein, vitamin C, flavonoid dan vitamin E (Willcox, Catignani dan Lazarus, 2003). Senyawa karotenoid tersebut memiliki keefektifan yang berbeda-beda dalam menjalankan fungsinya sebagai pelindung fotokimia (Sies, 1992). Dari semua senyawa karotenoid tersebut, ternyata likopen relatif lebih efisien sebagai penangkap singlet oksigen daripada karotenoid lainnya (lebih tinggi daripada B-karoten dan a-tokoferol). Likopen mempunyai kekuatan dalam menangkap singlet oksigen (ROS nonradikal) sebesar dua kali lipat dari kemampuan B-karoten (Bohm et al., 2002).

Tomat yang dihancurkan atau dimasak nampaknya menjadi sumber likopen lebih baik dibanding tomat utuh, karena selama proses pemanasan tersebut terjadi isomerisasi dan oksidasi. Konsumsi tomat yang tidak dimasak tidak akan meningkatkan konsentrasi serum likopen (Sies, 1992). Sebuah studi prospektif tentang produk tomat, likopen dan pengaruhnya terhadap resiko kanker membuktikan bahwa konsumsi produk olahan tomat atau likopen secara rutin dapat mengurangi resiko kanker prostat. Studi tersebut dilakukan sejak tahun 1986 hingga 1998. Subjek dari penelitian tersebut adalah 47365 orang laki-laki yang tidak terdiagnosis kanker prostat. Hasil dari peneliti- 
an tersebut menyatakan bahwa konsumsi saus tomat sebanyak 2 kali per minggu dapat menurunkan resiko kanker prostat (Giovannucci et al., 2002).

Sumber antioksidan lainnya yang sering diabaikan terdapat pada bekatul. Bekatul merupakan hasil sampingan dari penggilingan padi dan biasa dijadikan pakan ternak. Pada bekatul juga terdapat vitamin $B$ dari golongan tiamin, riboflavin, niasin (asam nikotinat) dan piridoxin. Dalam bekatul juga ditemukan komponen bioaktif, yakni zat yang di dalam tubuh bekerja di luar fungsi karbohidrat, lemak, protein, dan mineral. Komponen tersebut diantaranya tokoferol (vitamin E) tokotrienol, oryzanol dan asam pangamat (Kahlon, Chow dan Sayre, 1994; Damayanthi et al., 2003; Damayanthi et al., 2003).

Makanan memiliki peran yang sangat penting terhadap terjadinya penyakit kanker. Studi epidemiologi menunjukkan bahwa kebiasaan makan sayuran dan buah-buahan berbanding terbalik dengan kejadian kanker payudara, kanker mulut, kanker lambung, kanker usus besar, kanker pancreas, kanker endometrium, kanker uteri, kanker prostat dan kanker kandung kemih. Sebaliknya kebiasaan makan daging merah dan hasil olahannya menunjukkan hasil yang positif terhadap kejadian berbagai penyakit kanker (Lagio, 2002).

Penelitian ini bertujuan untuk mengukur nilai aktivitas antioksidan total pada jus tomat dan bekatul serta mengkaji pengaruh intervensi jus tomat dan minuman bekatul terhadap aktivitas antioksidan serum total wanita dengan kista dan tidak.

\section{METODE}

\section{Desain, Waktu dan Tempat Penelitian}

Penelitian ini merupakan penelitian eksperimental dengan percobaan lapang (field experiment) dan menggunakan pendekatan one group pretest posttest. Contoh terdiri atas dua kelompok perlakuan, yaitu kelompok nonkista (wanita bukan penderita kista payudara) dan kelompok kista (wanita penderita kista payudara).

Penelitian ini dilaksanakan pada bulan April 2009 hingga Mei 2010. Penelitian dilakukan di tiga lokasi yaitu untuk pembuatan jus tomat dan bekatul awet dilakukan di pilot plan SEAFAST Centre, Institut Pertanian Bogor. Intervensi dilakukan di Instalasi Deteksi Dini dan Onkologi Sosial serta Instalasi Radiodiagnostik
RS. Kanker Dharmais, Jakarta. Analisis aktivitas antioksidan total jus tomat dan bektaul serta serum dilakukan di Laboratorium Departemen Gizi Masyarakat Fakultas Ekologi Manusia, Institut Pertanian Bogor.

\section{Contoh Penelitian}

Pangan kaya antioksidan yang dipilih pada penelitian ini adalah jus tomat siap minum dan bekatul awet siap seduh. Contoh dipilih dari sejumlah populasi target yang telah didiagnosa oleh dokter di Instalasi Radiodiagnostik melalui beberapa tahap pemeriksaan. Apabila hasil pemeriksaan yang dilakukan memperkuat diagnosa awal bahwa subyek menderita kista payudara, memenuhi kriteria inklusi dan bersedia menandatangani informed consent maka pasien ditetapkan sebagai contoh.

\section{Persiapan Intervensi}

Pembuatan jus tomat didasarkan pada formulasi hasil penelitian yang telah dilakukan oleh Ginting (2008) mengenai pembuatan sari buah buah tomat rendah kalori kaya antioksidan. Buah tomat disortasi kemudian dilakukan proses bleaching selama 3 menit. Buah tomat tersebut kemudian dijus dan dikemas. Metode stabilisasi optimal bekatul awet dilakukan dengan cara pemanasan menggunakan otoklaf pada suhu $121^{\circ} \mathrm{C}$ selama tiga menit yang dilanjutkan dengan pengeringan menggunakan oven bersuhu $105^{\circ} \mathrm{C}$ selama satu jam (Damayanthi, 2002).

\section{Pengujian Aktivitas Antioksidan Total pada Pangan}

Sampel sebanyak 10 gram ditempatkan dalam botol sentrifuse, selanjutnya ditambahkan $100 \mathrm{ml}$ aseton 70\%. Sampel dicampur dengan shaker dengan kecepatan $35 \mathrm{rpm}$ selama 2 jam pada suhu kamar, kemudian disimpan pada suhu $-20{ }^{\circ} \mathrm{C}$ ditempat gelap selama 24 jam. Setelah 24 jam larutan dijaga keseimbangannya dengan equilibrium selama 1 jam pada suhu ruang. Larutan selanjutnya dipisahkan dengan sentrifuse selama 30 menit pada 3000 rpm. Residu sampel selanjutnya dicuci sebanyak 2 kali dengan menambahkan aseton $70 \%$, selanjutnya dicampur menggunakan shaker selama 1 jam dan dipisahkan kembali dengan sentrifuse selama 30 menit pada 3000 rpm. Tiga supernatan yang diperoleh ditampung pada erlenmeyer, disaring dengan kertas saring whatman no. 4 dengan bantuan pompa vakum, kemudian dikeringkan dengan rotary evaporator pada suhu $40^{\circ} \mathrm{C}$ untuk menguapkan aseton. Larutan sisa pengeringan dengan rota- 
ry evaporator selanjutnya dikeringkan kembali dengan menggunakan freeze dryer pada suhu $75{ }^{\circ} \mathrm{C}$. Ekstrak kering hasil freeze dryer yang didapat selanjutnya dijadikan sebagai larutan stok uji konsentrasi $200 \mathrm{mg} / \mathrm{ml}$ pelarut (Awika et al., 2003).

Buffer asetat 100 mM (pH 5.5) sebanyak $1.5 \mathrm{ml}$ ditempatkan pada tabung reaksi, kemudian ditambahkan $2.85 \mathrm{ml}$ etanol PA, $1 \mathrm{ml}$ DPPH $10 \mathrm{mM}$ dalam metanol dan $0.020 \mathrm{ml}$ ekstrak tomat dan bekatul. Campuran dicampur dengan vortex dan disimpan pada ruang gelap dengan suhu kamar selama 20 menit. Absorbansi dibaca pada panjang gelombang $517 \mathrm{~nm}$. Sebagai standar digunakan asam askorbat dengan konsentrasi $0 ; 6.25 ; 12.5 ; 25$; 50; dan $100 \mathrm{mg} / \mathrm{ml}$. satuan aktivitas antioksidan dinyataakan dalam AEAC (Ascorbic acid Equivalent Antioxidant Capacity) (Kubo et al., 2002). Aktivitas penangkapan radikal bebas dihitung sebagai persentase berkurangnya warna DPPH dengan menggunakan persamaan.

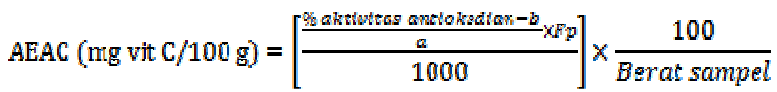

\section{Pelaksanaan Intervensi}

Sebelum dimulai intervensi jus tomat dan minuman bekatul, contoh melakukan diet rendah antioksidan selama dua minggu. Kemudian masing-masing contoh mendapat intervensi jus tomat selama dua minggu. Setelah intervensi jus tomat, contoh kemudian mendapat intervensi minuman bekatul awet selama dua minggu. Intervensi minuman bekatul dilakukan secara langsung, tanpa ada masa washout setelah pemberian jus tomat. Setelah selesai masa intervensi minuman bekatul selama 14 hari kemudian diambil kembali contoh darah dari masing-masing kelompok. Pengambilan sampel darah contoh kelompok non-kista dan kista dilakukan pada minggu ke-0 (sebelum intervensi), ke-2 (setelah periode intervensi jus tomat) dan 4 (setelah periode intervensi minuman bekatul) yang dilakukan oleh paramedis di RS Dharmais. Darah kemudian disimpan dan dibawa ke Klinik Nugraha, Bogor untuk kemudian dipisahkan serumnya.

\section{Pengukuran Aktivitas Antioksidan Total Serum}

Pengukuran aktivitas antioksidan serum dilakukan dengan metode DPPH (Carrapeiro et al. 2007). Prinsip pengujian metode DPPH adalah mereaksikan radikal bebas DPPH dengan antioksidan tubuh yang dapat diukur dari peru- bahan warna ungu DPPH menjadi warna kuning. Sebanyak $100 \mu \mathrm{L}$ sampel ditambahkan ke dalam $3.9 \mathrm{ml}$ larutan DPPH kemudian diaduk dengan vorteks hingga tercampur. Kemudian sampel dipisahkan dengan sentrifus pada kecepatan $4000 \mathrm{rpm}$ selama 25 menit. Nilai absorbansi contoh dibaca dengan spektrofotometer UV-Vis pada panjang gelombang 517 $\mathrm{nm}$. Sebagai kontrol dilakukan prosedur yang sama dengan persiapan sampel namun $100 \mu \mathrm{L}$ sampel diganti dengan $100 \mu \mathrm{L}$ air bebas ion.

Aktivitas antioksidan serum ditentukan oleh besarnya hambatan serapan radikal DPPH melalui perhitungan persentase inhibisi serapan DPPH dengan menggunakan rumus:

$\%$ Inhibisi $=\frac{\text { A kontrol }- \text { A sampel }}{\text { A kontrol }} \times 100 \%$

Keterangan: A kontrol: Serapan radikal DPPH pada $517 \mathrm{~nm}$ A sampel: Serapan radikal DPPH yang tersisa di dalam serum pada $517 \mathrm{~nm}$

\section{HASIL DAN PEMBAHASAN}

Hasil aktivitas antioksidan pada jus tomat dan bekatul awet dapat dilihat pada Tabel 1. Berdasarkan data pada Tabel 1 dapat diketahui bahwa besarnya aktivitas antioksidan total pada jus tomat dan bekatul berturut-turut adalah $60.74 \%$ dan $83.89 \%$. Hal ini mengindikasikan bahwa bekatul mempunyai kemampuan mereduksi radikal bebas lebih besar (efektif) dibandingkan sari buah tomat. Aktivitas antioksidan total bekatul lebih tinggi dibandingkan tomat dimana, rata-rata dalam 100 gram jus tomat mampu mereduksi radikal bebas DPPH setara dengan vitamin C sebanyak 1.87 kali, sedangkan bekatul mampu mereduksi radikal bebas DPPH yang setara dengan kemampuan vitamin $C$ sebesar 28.74 kali.

Tabel 1. Aktivitas Antioksidan pada Jus Tomat dan Bekatul Awet

\begin{tabular}{lcc}
\hline Jenis sampel & Absorbansi & AEAC $(\mathrm{mg} / 100 \mathrm{~g})$ \\
\hline Jus tomat & 0.117 & 1.87 \\
Bekatul & 0.048 & 28.74 \\
\hline
\end{tabular}

AEAC = Ascorbic acid Equivalent Antioxidant Capacity

Hasil analisis aktivitas antioksidan serum pada kelompok kista dan non-kista dapat dililihat pada Tabel 2 dan Gambar 1. Hasil pengukuran menunjukkan rata-rata aktivitas antioksidan kelompok kista cenderung lebih rendah daripada kelompok non-kista. Aktivitas 
antioksidan kelompok non-kista berkisar antara 24.59 - 28.59\%, sedangkan aktivitas antioksidan kelompok kista berkisar antara 11.56 29.04\%. Aktivitas antioksidan kelompok nonkista berkisar antara 5.78 - 17.19\%, sedangkan aktivitas antioksidan kelompok kista berkisar antara 13.04 - $21.19 \%$. Hasil pengujian menunjukkan bahwa aktivitas antioksidan serum setelah intervensi jus tomat kedua kelompok tersebut mengalami penurunan dibandingkan sebelum intervensi. Hasil pengujian aktivitas antioksidan pada serum darah minggu keempat tersebut menunjukkan adanya penurunan kembali aktivitas antioksidan pada kedua kelompok. Rentang aktivitas antioksidan kelompok non-kista berkisar antara 5.03 - 15.13\%, sedangkan rentang aktivitas antioksidan kelompok kista berkisar antara 4.13 - 15.73\%.

Tabel 2. Aktivitas Antioksidan Serum Contoh Setelah Intervensi Jus Tomat Siap Minum dan Bekatul Siap Seduh (\% Inhibition)

\begin{tabular}{|c|c|c|c|c|c|c|}
\hline \multirow{2}{*}{ Contoh } & \multicolumn{2}{|c|}{ Minggu ke- 0} & \multicolumn{2}{|c|}{ Minggu ke-2 } & \multicolumn{2}{|c|}{ Minggu ke-4 } \\
\hline & Non-kista & Kista & Non-kista & Kista & Non-kista & Kista \\
\hline 1 & 28.59 & 23.41 & 16.74 & 13.63 & 5.16 & 4.13 \\
\hline 2 & 24.59 & 29.04 & 17.19 & 16.30 & 15.13 & 5.47 \\
\hline 3 & 27.85 & 11.85 & 14.07 & 18.96 & 13.83 & 7.60 \\
\hline 4 & 26.52 & 24.89 & 16.44 & 13.33 & 12.16 & 5.60 \\
\hline 5 & 25.63 & 11.56 & 14.52 & 13.04 & 9.26 & 10.00 \\
\hline 6 & 25.63 & 26.37 & 5.78 & 21.19 & 5.03 & 15.73 \\
\hline 7 & 27.11 & 21.63 & 10.81 & 15.56 & 9.77 & 9.47 \\
\hline Rata-ra & 26.56 & 21.25 & 13.65 & 16.00 & 10.05 & 8.29 \\
\hline
\end{tabular}

Keterangan:

minggu ke-2 setelah periode intervensi jus tomat selama 14 hari, sedangkan minggu ke-4 adalah periode setelah intervensi minuman bekatul selama 14 hari
Pada Gambar 1 dapat dilihat pengaruh intervensi minuman jus tomat dan minuman bekatul terhadap rata-rata aktivitas antioksidan serum pada kelompok non-kista dan kista. Aktivitas antioksidan serum pada kedua kelompok setelah intervensi minuman jus tomat menurun dibandingkan dengan aktivitas antioksidan serum pada minggu ke-0. Aktivitas antioksidan pada kedua kelompok kembali turun setelah intervensi minuman bekatul.

Metode yang digunakan dalam pengujian aktivitas antioksidan adalah metode serapan radikal DPPH karena merupakan metoda yang sederhana, mudah, dan menggunakan sampel dalam jumlah yang sedikit dengan waktu yang singkat. Pemudaran warna mengakibatkan penurunan nilai absorbansi sinar tampak dari spektrofotometer, sehingga semakin rendah nilai absorbansi maka semakin tinggi aktivitas antioksidannya. Semakin pudar warna dan semakin rendah nilai absorbansi menunjukkan bahwa semakin banyak radikal bebas yang bereaksi dengan antioksidan yang terdapat dalam serum. Besarnya aktivitas antioksidan ditandai dengan nilai \% aktivitas antioksidan. Nilai aktivitas antioksidan dari sari buah tomat dan bekatul dapat dilihat pada Tabel 1.

Berdasarkan data pada Tabel 1 dapat diketahui bahwa besarnya aktivitas antioksidan pada jus tomat dan bekatul berturut-turut adalah $60.74 \%$ dan $83.89 \%$. Hal ini mengindikasikan bahwa bekatul mempunyai kemampuan mereduksi radikal bebas lebih besar (effektif) dibandingkan sari buah tomat. Rata-rata dalam 100 gram jus tomat dan bekatul masing-masing mampu mereduksi radikal bebas DPPH yang setara dengan kemampuan $1.87 \mathrm{mg}$ dan 28.74 $\mathrm{mg}$ vitamin $\mathrm{C}$.

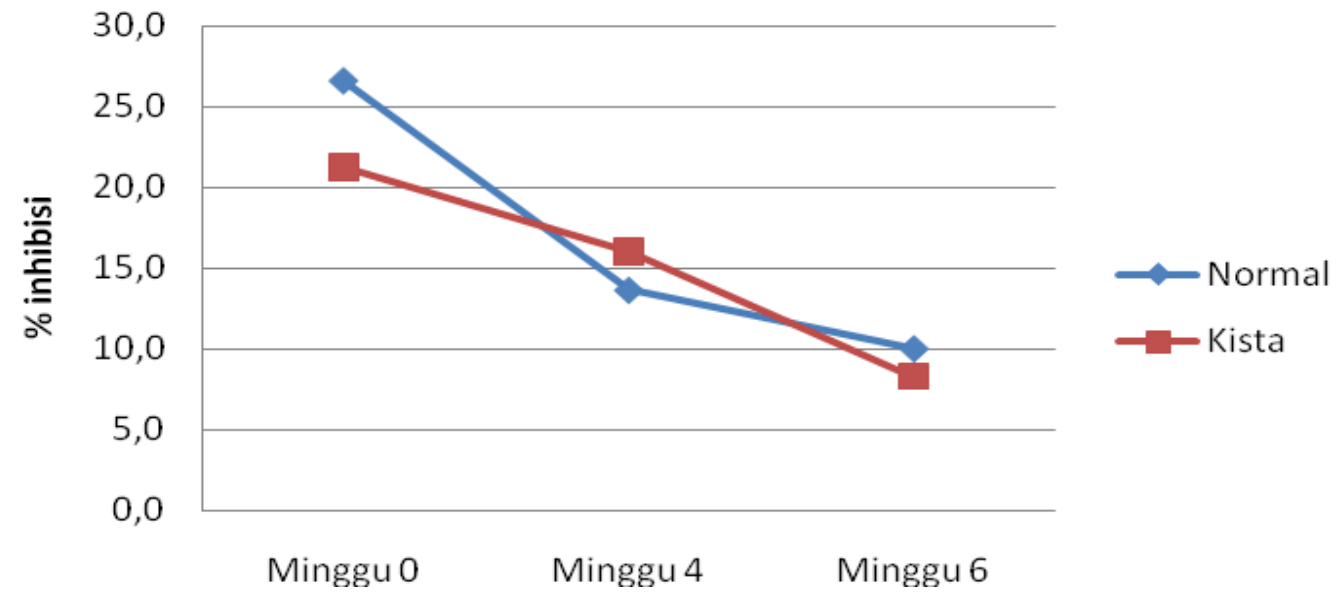

Gambar 1. Rata-rata Pengaruh Intervensi Minuman Jus Tomat dan Minuman Bekatul terhadap Aktivitas Antioksidan Kelompok Non-kista dan Kista (\%) 
Aktivitas antiradikal serum yang terukur dengan metode DPPH dinyatakan dalam satuan persentase inhibisi. Hasil pengukuran menunjukkan hasil yang beragam. Setelah intervensi selama 2 minggu pertama dengan minuman jus tomat, kemampuan serum untuk menghambat reaksi dengan radikal DPPH menurun dibandingkan sebelum intervensi. Kemampuan serum untuk menghambat reaksi dengan radikal DPPH kembali menurun setelah intervensi dengan minuman bekatul selama 2 minggu. Aktivitas antioksidan serum setelah intervensi minuman jus tomat turun dibandingkan dengan sebelum intervensi $(p>0.05)$, namun baru terlihat nyata setelah intervensi minuman bekatul $(p<0.05)$. Penurunan aktivitas antioksidan yang terjadi pada serum yang diintervensi jus tomat dan terutama minuman bekatul diduga terjadi karena antioksidan likopen atau tokoferol, tokotrienol dan orizanol di dalam serum telah digunakan tubuh untuk melindungi tubuh dengan cara terlebih dahulu telah bereaksi dengan prooksidan. Hasil penelitian yang serupa telah ditunjukkan oleh Carrapeiro et al. (2007) dimana kapasitas antioksidan pada plasma darah tikus yang mengkonsumsi pakan kaya akan asam lemak EPA(C20:5) dan DHA (C22:6) serta disuplementasi dengan likopen menjadi turun. Hal tersebut dijelaskan diduga diakibatkan oleh aktivitas likopen dalam menangkal reaksi radikal bebas yang terdapat dalam tubuh dan ditunjukkan oleh kadar malonaldehid darah yang tidak berubah. Hasil penelitian menunjukkan bahwa penurunan aktivitas antioksidan serum setelah intervensi minuman bekatul lebih nyata dibandingkan yang diintervensi jus tomat, mungkin hal ini terkait dengan aktivitas antioksidan total minuman bekatul yang jauh lebih besar dibandingkan jus tomat, yaitu hampir 15 kali.

\section{KESIMPULAN}

Nilai aktivitas antioksidan total pada bekatul lebih tinggi daripada jus tomat, dimana rata-rata dalam 100 gram jus tomat mampu mereduksi radikal bebas DPPH setara dengan vitamin C sebanyak 1.87 kali, sedangkan bekatul mampu mereduksi radikal bebas DPPH yang setara dengan kemampuan vitamin $C$ sebesar 28.74 kali.

Aktivitas antioksidan serum setelah intervensi minuman jus tomat turun dibandingkan dengan sebelum intervensi $(p>0.05)$, namun baru terlihat nyata setelah intervensi minuman bekatul $(p<0.05)$.
Pemanfaatan bekatul sebagai pangan manusia masih terbatas maka perlu upaya upaya yang lebih kuat untuk mengajak wanita yang beresiko tinggi kanker payudara agar mau mengonsumsi minuman bekatul. Untuk penelitian yang akan datang perlu dianalisis kadar hormon estrogen darah untuk menjelaskan pengaruh antioksidan terhadap kadar estrogen darah.

\section{DAFTAR PUSTAKA}

Awika JM, Rooney LW, Wu X, Prior LR \& Zevallos LC. 2003. Screening Methods to Measure Antioxidants Activity of Sorghum (Sorghum bicolor) and Sorghum Products. J Agricultural Food Chemistry, 51(23), 6657-6662.

Bohm V, Puspitasari-Nienaber NL, Ferruzi MG \& Schwart SJ. 2002. Trolox equivalent antioxidant capacity of different geometrical isomer of a-carotene, B-carotene, lycopene and zeaxanthin. J Agric. Food Chem, 50, 221-226

Carrapeiro et al. 2007. Effect of lycopene on biomarkers of oxidative stress in rats supplemented with $\omega-3$ polyunsaturated fatty acid. Food Research International, 40, 939-946

Damayanthi E. 2002. Karakteristik bekatul padi (Oryza sativa) awet serta aktivitas antioksidan dan penghambatan proliferasi sel kanker secara in vitro dari minyak dan fraksinya. Disertasi Doktoral Program Pascasarjana, Program Studi Ilmu Pangan, Institusi Pertanian Bogor, Bogor.

Damayanthi E et al. 2003. Pengaruh derajat sosoh terhadap kandungan gizi, serat pangan dan oryzanol bekatul padi (Oryza sativa) awet. Media Gizi dan Keluarga No. 19.

et al. 2003. Aktivitas antioksidan minyak bekatul awet dan fraksinya secara in vitro. Jurnal Teknologi dan Industri Pangan, XV, 1.

Giovannucci et al. 2002. A Prospective Study of Tomato Products, Lycopene and Prostate Cancer Risk. Journal of the National Cancer Institute, 94(5). 
Halliwell B \& Guteridge JMC. 1991. Free Radical in Biology and Medicine. Clarendon Press, Oxford.

Kahlon TS, Chow FI \& Sayre RN. 1994. Cholesterol-Lowering Properties of Rice Brain. Journal of Cereal Food Word, 39(2), 99102

Kubo I, Masuda N, Xiao P \& Haraguchi H. 2002. Antioxidant Activity of Deodecyl Gallate. J. Agric. Food Chem, 50, 3533-3539

Lagio PA. 2002. Nutritional epidemiology of cancer: accomplishment and prospect. Prosiding of The Nutritional Society, 61, 217-222
Meydani et al. 1995. Antioxidants and Immune Response in Aged Persons: Overview of Present Evidence. American Journal of Clinical Nutrition, 62, 1462S-1476S

Sies H. 1992. Antioxidant Functions of Vitamin: vitamins $E$ and $C, B$-carotene and other carotenoids. Ann N Y Acad. Ci, 69, 7-20.

Willcox JK, Catignani GL \& Lazarus S. 2003. Tomatoes and cardiovascular Health. Critical Rev. in Food Sci and Nut, 43 (1),1-18.

Winarsi H. 2007. Antioksidan Alami dan Radikal Bebas. Kanisius, Yogyakarta. 